УДК 636.4: 619: 615: 619: $616.34-002$

(C) 2016

\author{
Шатохін П. П., Супруненко К. В., кандидати ветеринарних наук, \\ Каришева Л. П., старший викладач
}

Полтавська державна аграрна академія

\title{
ВПЛИВ «ХОРІОЦЕНУ» НА ДЕЯКІ БІОХІМІЧНІ ПОКАЗНИКИ КРОВІ У ПІДСИСНИХ СВИНОМАТОК
}

\section{Рецензент - доктор ветеринарних наук А. А. Замазій}

У роботі представлені результати наукових досліджень щзодо розробки та впровадження у ветеринарну практику екологічно чистих препаратів, а саме плацентарних, здатних нормалізувати метаболічні процеси у тканинах, та відновлювати структуру та функиії органів і систем організму. Встановлено, щзо двократне введення хоріочену збільшує вміст білка в крові на 1,5\% у порівнянні з показником периої доби після опоросу та на 5,3 \% - показника тварин контрольної групи на 28-му добу. Вміст глюкози після введення препарату збільшився у всіх групах $p<0,001$, але у дослідних групах ией показник був вищим, ніж у контрольній на 8,7, 7,0 та 6,1\%. На фоні гіперфосфатемії вміст неорганічного фосфору в крові свиноматок 3-ї дослідної групи на 28-му добу був на $17 \%$ нижчим, ніж у свиноматок групи контролю.

Ключові слова: свиноматки, плачентарні препарати, біохімічні показники, пуповина десмургована емульгована (ПДЕ).

Постановка проблеми. Профілактика хвороб тварин $\epsilon$ однією $з$ найважливіших складових сучасних технологій ведення тваринницької галузі. При цьому, особливу увагу приділяють контролю обмінних процесів в організмі тварин в різні періоди їх продуктивного циклу, зокрема на рівні взаємодії «організм матері-плід-новонароджена тварина».

Дефіцит або порушення співвідношення в раціонах годівлі тварин поживних речовин (білки, вуглеводи, ліпіди) та біологічно активних речовин (макро- і мікроелементи, вітаміни), вплив на організм тварин несприятливих факторів довкілля (порушення мікроклімату в приміщеннях, згодовування недоброякісних кормів тощо) спричиняють розвиток патології обміну речовин i $€$ етіологічним чинником виникнення в них імунодефіцитного стану та розвитку хвороб.

На даний час актуальною проблемою $є$ розробка екологічно чистих ветеринарних препаратів, здатних підвищувати імунну резистентність організму тварин, нормалізувати метаболічні процеси у тканинах, відновлювати структуру та функції органів і систем організму.

3 огляду на важливість цього питання, вико- ристання ветеринарних препаратів тваринного походження є ефективною альтернативою існуючим традиційним підходам щодо профілактики порушень обміну речовин в організмі тварин та виникнення в них системних захворювань. Окрім того, розробка і застосування таких препаратів тваринам різних видів $\epsilon$ запорукою отримання здорового потомства та високоякісної тваринницької продукції.

Аналіз основних досліджень i публікацій, у яких започатковано розв'язання проблеми. Хвороби, які характеризуються порушенням обміну речовин в організмі тварин, становлять 30 $35 \%$ від усіх захворювань незаразної етіології. Більше того, у молодняку тварин низка хвороб апарату травлення, дихання, серцево-судинної системи тощо, зазвичай, виникають і набувають розвитку тоді, коли первинним фактором $є$ саме порушення метаболічних процесів в організмі їх матерів.

Поширення хвороб, викликаних порушенням обміну речовин в організмі свиноматок в окремих областях України становить від 25 до $43 \%$. Водночас захворюваність поросят шлунковокишковими розладами (диспепсія, гастроентерит), одержаних від цих свиноматок, становить до 20-25\%, залежно від регіону України [8].

Для лікування та профілактики метаболічних порушень в організмі сільськогосподарських тварин поширюється використання тканинних препаратів тваринного походження 3 плацентарної сировини, які на противагу очищеним і синтезованим препаратам містять гормони, біогенні стимулятори та інші речовини у концентраціях, наближених до фізіологічних. У формі витяжки 3 тканин плаценти такі біологічно активні сполуки можуть проявляти свою дію як комплексно, так i спрямовано, що залежить від методики приготування та схеми застосування препарату [2].

Значний внесок у виготовлення та випробування плацентарних препаратів внесли Д. М. Голбан і М. С. Рейлян [3]. За оригінальними методиками нами були створені препарати «Умбіліцен», «Хоріоцен», «Амніоцен», ПДЕ. Клінічні 


\section{ВЕТЕРИНАРНА МЕДИЦИНА}

випробування показали високу терапевтичну ефективність цих препаратів за гострих та хронічних ендометритів, маститів у корів та свиноматок. Парентеральне введення «Хоріоцену» підсисним свиноматкам попереджувало розвиток молозивного токсикозу у поросят, збільшувало масу тіла та позитивно впливало на збереженість поросят сисунів [4]. Встановлено, що плацентарні препарати профілактують розвиток синдрому пероксидації у корів і свиноматок $[4,9]$.

Дослідження Е. І. Шуманової [10], С. Ф. Назимкиної [6] та А. М. Никитенко [7] підтвердили високу ефективність препаратів 3 плаценти за акушерських і гінекологічних захворювань та їх вплив на імунобіологічну реактивність організму тварин.

Мета дослідження - визначити вплив плацентарного препарату «Хоріоцен» на організм свиноматок.

Об'єкт дослідження - підсисні свиноматки.

Суб'єкт дослідження - біохімічні показники сироватки крові.

Завдання дослідження:

a) за принципом аналогів сформувати три дослідних та одну контрольну групи підсисних свиноматок за два дні до опоросу;

б) свиноматкам у першу добу після опоросу ввести препарат «Хоріоцен» згідно з розробленою схемою;

в) визначати та проаналізувати окремі біохімічні показники крові за два дні до опоросу, в день опоросу та на 28-му добу досліджень.

Матеріали та методи досліджень. Для проведення експерименту були сформовані чотири групи поросних свиноматок за принципом аналогів, за два дні до опоросу (три дослідних, одна контрольна) за наступною схемою:

- перша дослідна група (6 голів) - внутрішньом'язово вводили «Хоріоцен» у дозі 10 мл, триразово, перша ін'єкція через 4 години після опоросу, друга - на 3-ю добу та третя - на 15-у добу після опоросу;

- друга дослідна група (6 голів) - «Хоріоцен» вводили внутрішньом'язово у дозі 10 мл, одноразово, через 4 години після опоросу;

- третя дослідна група (6 голів) - внутрішньом'язово вводили «Хоріоцен» у дозі 10 мл, дворазово, через 4 години після опоросу та на 3-ю добу досліду;

- четверта контрольна група (6 голів) - жодних фармакологічних засобів не застосовували.

Для проведення гематологічних досліджень кров у свиноматок відбірали з хвостової артерії. Перший відбір проб крові був за два дні до опоросу вибірково, другій - на першу добу до введення препаратів, третій - на 28-му добу після опоросу. В сироватці крові визначали вміст загального білка рефрактометричним методом, глюкози - за кольоровою реакцією з ортотолуїдином, кетонових тіл - йодометричним методом, загального кальцію - комплексонометричним методом 3 індикатором флуорексоном, неорганічного фосфору - за ванадат-молібденовою реакцією [5]. Для кожної групи показників була проведена статистична обробка з визначенням помилки середньої арифметичної $(\mathrm{M} \pm \mathrm{M})$ та вірогідної різниці (р) по відношенню до першого дослідження [11].

Результати досліджень. Вміст загального білка у сироватці крові свиноматок за два дні до опоросу та в день опоросу знаходився в межах фізіологічних коливань ( $\operatorname{Lim} 8,1-8,2$ г\%) (див. табл.).

\section{Показники біохімічних досліджень}

\begin{tabular}{|c|c|c|c|c|c|c|}
\hline \multirow{3}{*}{ Показники } & \multirow{3}{*}{$\begin{array}{c}\text { За } 2 \text { дні } \\
\text { до } \\
\text { опоросу }\end{array}$} & \multirow{3}{*}{$\begin{array}{c}1 \text { день } \\
\text { після } \\
\text { опоросу }\end{array}$} & \multicolumn{4}{|c|}{ На 28-му добу після опоросу } \\
\hline & & & \multicolumn{4}{|c|}{ Групи } \\
\hline & & & 1 дослідна & 2 дослідна & 3 дослідна & контрольна \\
\hline $\begin{array}{c}\text { Загальний } \\
\text { білок, г\% }\end{array}$ & $8,1 \pm 0,3$ & $8,2 \pm 0,17$ & $7,86 \pm 0,3$ & $7,7 \pm 0,25$ & $8,32 \pm 0,5$ & $7,9 \pm 0,13$ \\
\hline $\begin{array}{c}\text { Загальний } \\
\text { кальцій, мг\% }\end{array}$ & - & $9,7 \pm 0,3$ & $10,0 \pm 0,3$ & $10,0 \pm 0,38$ & $10,5 \pm 0,2$ & $10,2 \pm 0,2$ \\
\hline $\begin{array}{c}\text { Неорганічний } \\
\text { фосфор, мг\% }\end{array}$ & - & $5,3 \pm 0,4$ & $8,4 \pm 0,3 * * *$ & $8,8 \pm 0,3 * * *$ & $7,5 \pm 0,7^{*}$ & $8,8 \pm 0,4 * * *$ \\
\hline Глюкоза, мг\% & $38,6 \pm 6,1$ & $35,0 \pm 1$ & $62,4 \pm 1,0 * * *$ & $60,9 \pm 2,2 * * *$ & $61,1 \pm 3,8 * * *$ & $57,6 \pm 1,5 * * *$ \\
\hline $\begin{array}{c}\text { Кетонові тіла, } \\
\text { мг\% }\end{array}$ & $2,4 \pm 0,04$ & $2,1 \pm 0,2$ & $3,6 \pm 0,3 * * *$ & $2,6 \pm 0,13$ & $3,2 \pm 0,4 * *$ & $3,7 \pm 0,3^{* *}$ \\
\hline
\end{tabular}

Примітка: * - $<<0,05 ; * *-p<0,01 ; * * *-p<0,001$ по відношенню до показників першої доби після опоросу. 


\section{ВЕТЕРИНАРНА МЕДИЦИНА}

Вміст загального білка у сироватці крові свиноматок на 28-му добу після опоросу у всіх дослідних та контрольній групах відповідав показникам норми і був у межах 7,7-8,32 г\%. У подальшому, цей показник у свиноматок 1-ї, 2-ї дослідних і контрольної груп мав тенденцію до зниження відносно такого у першу добу опоросу, відповідно, на 5,7 та 4 \%. Вміст загального білка у сироватці крові тварин 3-ї дослідної групи на 28-му добу досліду становив 8,32 $\pm 0,5$ г\%, що відповідає верхній межі фізіологічних коливань та вище на $3 \%$ за показник першої доби після опоросу.

Отже, зменшення вмісту загального білка в сироватці крові підсисних свиноматок, імовірно, $\epsilon$ фізіологічним явищем, яке пов'язане зі збільшенням об'єму в циркулюючій крові білка та посиленням його видалення з молозивом і молоком $[1,9]$.

Дослідження показника вмісту загального кальцію у сироватці крові свиноматок у перший день

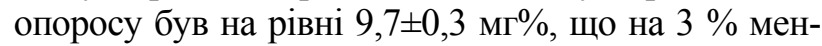
ше нижньої межі фізіологічних коливань. У подальшому відбулось незначне його збільшення до показників нижньої межі норми (Lim 10,010,5 мг\%).

Вміст неорганічного фосфору в сироватці крові свиноматок на початку досліду становив $5,3 \pm 0,4$ мг\%. На 28-му добу в організмі тварин всіх дослідних груп було встановлено гіперфосфатемію. 3 середнім та високим ступенем вірогідності для 1-ї, 2-ї дослідних і контрольної груп $\mathrm{p}<0,001$ для 3-ї дослідної групи $\mathrm{p}<0,05$.

Підвищення вмісту неорганічного фосфору в сироватці крові підсисних свиноматок пов'язано, можливо, зі зменшенням секреції паратгормону, який відповідає за реабсорбцію фосфору в нирках. Причиною зниження секреції гормону може бути малорухливість тварин та недостатність у раціоні вуглеводів.

Вміст глюкози в сироватці крові свиноматок за два дні до опоросу та на перший день опоросу був нижче фізіологічних коливань і знаходився в межах 35,0-38,6 мг\% за норми 80-100 мг\%.

На 28-му добу в усіх дослідних і контрольній групах вміст глюкози в сироватці крові підсисних свиноматок збільшився відносно показника

\section{БІБЛІОГРАФІЯ}

1. Ветеринарна клінічна біохімія / [Карташов М. І., Тимошенко О. П., Кібкало Д. В. та ін.] ; за ред. М. І. Карташова та О. П. Тимошенко. - Х. : Еспада, 2010. - 400 с.

2. Востроилова Г.А. Экспериментальная и клиническая фармакология препаратов плацен- на день опоросу $(35,0 \pm 6,1$ мг\%) і становив у до-

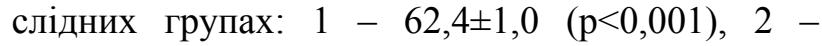
$60,9 \pm 2,2(\mathrm{p}<0,001)$ та 3 група $-61,1 \pm 3,8$ мг\%. У тварин контрольної групи цей показник також збільшився і становив 57,6 $\pm 1,5$ мг\%, $(\mathrm{p}<0,001)$, проте відносно показників дослідних груп він був нижче: до 1-ї дослідної групи на 8,6 \%, 2-ї $7 \%$, 3-ї на 6,1\% $(\mathrm{p}<0,001)$.

Результати визначення вмісту глюкози в сироватці крові свиноматок дають нам змогу вважати стан тварин як гіпоглікемічний. На нашу думку, причиною гіпоглікемії в даному господарстві $€$ недостатність легкоперетравних вуглеводів в раціоні за висококонцентратного типу годівлі.

Вміст кетонових тіл у сироватці крові свиноматок за два дні до опоросу та в день опоросу коливався в фізіологічних межах (Lim 2,1-2,4 мг\%). На 28-му добу досліду в усіх дослідних групах і контрольній цей показник збільшився, перевищуючи межі фізіологічних коливань норми (Lim 2,6-3,6 мг\%). Найменша вірогідність підвищення вмісту кетонових тіл відбувалася в другій дослідній групі (19\%). У другій, третій дослідних та контрольній групах уміст кетонових тіл вірогідно збільшився $(\mathrm{p}<0,01)$.

Підвищення вмісту кетонових тіл у сироватці крові підсисних свиноматок у даному господарстві є наслідком недостатнього забезпечення тварин вуглеводами, що призводить до глибоких порушень не тільки обміну ліпідів, але й білків, оскільки організм, у такому разі, вимушений використовувати для енергії вище вказані сполуки. Водночас це супроводжується утворенням та накопиченням у тканинах великої кількості недоокислених продуктів. Додатковим чинником збільшення кетонових тіл у підсисних свиноматок є фаза інтенсивної лактації [1].

Висновок. Введення підсисним свиноматкам плацентарного препарату «Хоріоцен» внутрішньом'язово одно, дво- та триразово не впливає негативно на досліджені біохімічні показники сироватки крові.

Тканинний препарат «Хоріоцен», введений внутрішньом'язово свиноматкам дослідних груп, сприяв підвищенню вмісту глюкози у сироватці крові по відношенню до тварин контрольної групи на 8,6, 7 та 6,1 \% відповідно.

ты, полученных методом криофракционирования : дис. ... д.б.н. : 16.00.04, 03.00.04 / Г. А. Востроилова. - Воронеж : ВНИВИП, 2007. - 350 с.

3. Голбан Д. М. Новые тканевые препараты для ветеринарных целей / Д. М. Голбан, Н. С. Рейлян // сб. Новые препараты в ветеринарии. - Ки- 


\section{ВЕТЕРИНАРНА МЕДИЦИНА}

шинев, 1990. - С. 4-8.

4. Голбан Д. М. Тканевой препарат хориоцен в сочетании с дилудином и альфа-токоферолом профилактирует молозивный токсикоз у поросят / Д. М. Голбан, С. Д. Баланеску // сб. Новые препараты в ветеринарии. - Кишинев, 1990. - С. 9-11.

5. Методы ветеринарной клинической лабораторной диагностики : справочник / [под ред. проф. И. П. Кондрахина]. - М. : Колос С, 2004. $520 \mathrm{c}$.

6. Назимкина С. Ф. Применение плаценты денатурированой эмульгированной для профилактики и лечения послеродовых осложнений у коров / С. Ф. Назимкина // Ветеринарная медицина (Россия). - 2009. - №1-2. - С. 5.

7. Никитенко А. М. Повышение иммунобиологической реактивности сельскохозяйственных животных с помощью тканевых препаратов: методические указания в помощь слушателям ФПК / А. М. Никитенко. - Белая Церковь : БГАУ, 1989. $24 \mathrm{c}$.

8. Практичні рекомендації з лікування та профілактики порушень обміну речовин у свинома- ток та шлунково-кишкових розладів у поросят 3 використанням біогенних сполук мікроелементів / [Цвіліховський М. І., Береза В. І., Вержиховський О. М. та ін.]. - К. : НУБІП України, 2009. $21 \mathrm{c}$.

9. Шатохін П. П. Вплив тканинного препарату «Хоріоцен» на показники еритроцитопоезу у підсисних свиноматок та збереженість поросятсисунів / П. П. Шатохін, К.В.Супруненко, Л. П. Каришева / Наук. праці Полтавської держ. аграр. акад. - Серія : Ветеринарна мед. - Полтава : РВВ Полтавської держ. аграр. акад., 2014. Вип. 7. - С. 73-79.

10. Шурманова Е. И. Применение препаратов из плаценты при акушерских и гинекологических заболеваниях у коров : дис. ... к.вет.н. : 16.00.07 / Е. И. Шурманова. - Екатеринбург, 2006. $-155 \mathrm{c}$.

11. Яблонський В. Наукознавство: основи наукових досліджень у тваринництві та ветеринарній медицині / В. Яблонський, О. Яблонська. K., 2007. -332 c. 